\title{
KIA WHAKATŌMURI TE HAERE WHAKAMUA: IMPLEMENTING TIKANGA MĀORI AS THE JURISDICTIONAL FRAMEWORK FOR OVERLAPPING CLAIMS DISPUTES
}

\author{
Rhianna Eve Morar*
}

\begin{abstract}
This article addresses the misconception that overlapping rights to land are always in tension with one another. In this article, I apply a tikanga-based analysis to the policy on overlapping rights that is used in the settlement of historical Treaty of Waitangi claims. I argue that the supremacy of colonial law within the State legal system continues to suppress indigenous relationality and limit the mechanisms for reciprocity. This article problematises the following claims made about overlapping claims disputes. First, that overlapping rights are too complex for judicial resolution. This article examines the ways in which overlapping rights are capable of co-existing to preserve relationships between different iwi and hapu. Second, that tikanga is a contestable system of law and should not be regarded as a question of law or as a jurisdictional framework for resolving such disputes. This article critically analyses the extent to which these claims are based on the supremacy of colonial law within the State legal system by considering the application of tikanga in the courts and alternative dispute resolution processes. I argue that tikanga Mäori is the only applicable framework whereby differences can be mediated in a way that preserves the relationships between the parties and provides redress mechanisms for continuing reciprocity. This article concludes that the State legal system at present continues to delegitimise indigenous relationality in ways that amalgamate rights into a colonial recognition framework, which fails to recognise tikanga Māori as an equal system of law in Aotearoa New Zealand.
\end{abstract}

* Ngāti Porou, Te Arawa (Tapuika). Originally submitted for the LLB(Hons) degree, Faculty of Law, Victoria University of Wellington, 2020. I would like to thank Associate Professor Dr Carwyn Jones for his thoughtful supervision and influence on this article through his teaching at the Faculty of Law. 


\section{INTRODUCTION}

There is a misconception that overlapping rights to land are always in tension with one another. I argue that the State legal system is incapable of recognising the extent to which overlapping rights are informed by the principle of reciprocity. In considering this argument, the following points will be addressed. First, overlapping rights must be recognised within the cultural context from which they derive. Part II of this article identifies a number of constraints sourced in colonialism which the State legal system imposes. In Part III, I explain that where overlapping rights are considered within their cultural context, tikanga Māori becomes the only jurisdictional framework capable of providing reciprocal redress. The problem is that the Treaty of Waitangi settlement process continues to supress the ways in which tikanga can speak on overlapping claims disputes.

In Parts IV and V, I address some of the challenges within the Treaty settlement process. I explain how the current policy for resolving overlapping claims provides a paradoxical framework that purports to empower Māori to exercise tino rangatiratanga in settling their own disputes, but only in so far as it conforms to the colonial framework. This article shows that this type of legal recognition continues to perpetuate the supremacy of rights as negotiated by the Crown, at the expense of rights as grounded in tikanga. This is problematic because the use of tikanga-based processes is an essential part of the Crown's duty to avoid creating fresh grievances. I suggest that to employ a non-customary framework is to balance out the potential for overlapping rights to co-exist, instead favouring notions of exclusivity, absolute ownership and efficiency.

In Parts VI and VII, I consider the ways in which tikanga is implemented within the State legal system. I argue that the recognition of tikanga as a jurisdictional framework is burdened by the supremacy of colonial law. The increasing litigation of overlapping claims disputes demonstrates that the Treaty settlement process is not working. Despite this, the courts continue to operate on the assumption that overlapping claims are incapable of conventional judicial resolution and that tikanga principles are not questions of law. I suggest that it is wrong to use the diverse practices of tikanga to justify claims that tikanga as a body of law is contested and, therefore, should not be regarded as a ground of appeal. This approach continues to entrench the assimilatory practices of the Native Land Court.

Overall, I conclude that the persistence of law grounded solely in Western sources distorts the substance of a right that would otherwise be given proper recognition under tikanga. This article shows that the current mechanisms for resolving overlapping claims are so limited and ignorant of tikanga that Māori will continue to be coerced into reconceptualising their rights to be palatable to the colonial recognition framework.

\section{THE CONSTRAINTS OF THE COLONIAL SYSTEM}

There are significant limitations on the extent to which state law may provide for Māori jurisdictional autonomy. The alternative dispute resolution processes discussed in this article should 
not be mistaken for Māori dispute resolution. ${ }^{1}$ This problem is best addressed by acknowledging that the ability of State law to understand rights and interests as grounded in tikanga Māori will not provide an independent right for Māori to exercise jurisdictional autonomy in the definition and determination of their own justice. ${ }^{2}$ This article instead identifies the ways in which the State legal system may be used to interrogate the colonial assumptions of the law in order to recognise tikanga Māori as the proper jurisdictional framework for resolving disputes.

More significantly, this article recognises that the courts are not the most appropriate body to determine customary rights and interests according to tikanga. ${ }^{3}$ However, the increasing litigation of overlapping claims disputes suggests that when Māori engage with the State legal system, they bring their tikanga with them. ${ }^{4}$ It is therefore a matter of practical reality that these processes are structured in a way that allows tikanga to be applied safely, so that customary rights and interests may be understood and recognised within their cultural context. ${ }^{5}$ Where dispute resolution processes are perceived to reflect and implement tikanga, there is greater potential for Māori legal traditions to transform the way in which the State legal system engages with customary rights and interests, and to consider whether the proposed redress is capable of giving effect to those rights. ${ }^{6}$

The nature of overlapping claims disputes has led the High Court to consider tikanga as a contestable (and therefore illegitimate) body of law. ${ }^{7}$ Although tikanga is very much contextdependent, the Court suggests there is "no clear bright line of tikanga which [can] be applied to

1 Amokura Kawharu "Arbitration of Treaty of Waitangi Settlement Cross-Claim Disputes" (2018) 29 PLR 295 at 306; Ani Mikaere "Tikanga as the First Law of Aotearoa" in Linda Te Aho (ed) Tikanga Māori me te Mana $i$ Waitangi: Māori Laws and Values, Te Tiriti o Waitangi, and Human Rights (University of Waikato School of Law, Waikato, 2007) 24 at 24-26; and Nin Tomas and Khylee Quince "Māori Disputes and Their Resolution" in Peter Spiller (ed) Dispute Resolution in New Zealand (Oxford University Press, Oxford, 1999) 205 at $217-218$.

2 Moana Jackson "Justice and Political Power: Reasserting Māori Legal Processes" in Kayleen Hazlehurst (ed) Legal Pluralism and the Colonial Legacy (Avebury, Aldershot, 1995) 243 at 261.

3 Robert Joseph "Re-Creating Legal Space for the First Law of Aotearoa-New Zealand" (2009) 17 Wai L Rev 74 at 92; Moana Jackson "It's Quite Simple Really" in Linda Te Aho (ed) Tikanga Mãori me te Mana i Waitangi: Māori Laws and Values, Te Tiriti o Waitangi, and Human Rights (University of Waikato School of Law, Waikato, 2007) 32 at 35; Ani Mikaere Colonising Myths Māori Realities: He Rukuruku Whakaaro (Huia, Wellington, 2011) at 268; and Stephanie Milroy "Ngā Tikanga Māori and the Courts" in Linda Te Aho (ed) Tikanga Māori me te Mana i Waitangi: Māori Laws and Values, Te Tiriti o Waitangi, and Human Rights (University of Waikato School of Law, Waikato, 2007) 15 at 19.

4 See Ngāti Whātua Ōrākei v Attorney-General [2018] NZSC 84, [2019] 1 NZLR 116; Bidois v Leef [2017] NZCA 437; and Ngāti Hurungaterangi v Ngāti Wahaio [2017] NZCA 429, [2017] 3 NZLR 770 (CA).

5 Milroy, above n 3, at 22-23.

6 Carwyn Jones New Treaty, New Tradition: Reconciling New Zealand and Māori Law (Victoria University Press, Wellington, 2016) at 131.

7 Ngāti Hurungaterangi v Ngāti Wahiao [2016] NZHC 1486, [2016] 3 NZLR 378 (HC). 
determine the competing claims of mana whenua to ... land." 8 The diverse practices of tikanga are therefore invoked as a reason to deny the applicability of Māori law on the basis of its "imprecise" and "changeable" aspects. ${ }^{9}$ Under this approach, tikanga is wrongfully limited to questions of fact, rather than questions of law. Amokura Kawharu has argued that this imposes a hurdle on Māori disputants that is otherwise unapplicable to non-Māori and perpetuates the treatment of tikanga as a secondary or foreign source of law in New Zealand. ${ }^{10}$ Although the courts rightfully take a cautious approach when attempting to determine the substance of tikanga, its variation has always been inherent to the operation of Māori law and does not reduce its legitimacy as a legal system with distinct legal characteristics. ${ }^{11}$

The search for an unequivocal legal principle to resolve overlapping claims would be contrary to Māori legal traditions as it would delegitimise the diversity of rights as they exist in law. Diversity in tikanga is healthy, so long as the conceptual regulators that guide its application are maintained. Anything less creates the erroneous impression that tikanga is a homogenous body of law and that differing applications of tikanga should not be considered "legal" disputes. ${ }^{12}$

\section{OVERLAPPING RIGHTS THROUGH THE LENS OF INDIGENOUS RELATIONALITY}

The substance of a right must be informed by the legal system from which it derives. ${ }^{13}$ Overlapping rights and interests must therefore be considered within the broader tikanga matrix that guides the relationships between rights-holders. However, the Treaty settlement framework only recognises these rights to the extent that they conform to the redress offered by the Crown. This is problematic because redress is characterised by Western theories of property, based on notions of

8 At [129].

9 At [130].

10 Kawharu, above n 1, at 306.

11 Mikaere, above n 3, at 264-265.

12 Kawharu, above n 1, at 306.

13 The Canadian courts have adopted the approach that the content of aboriginal title must be determined by Indigenous law and custom: $R v$ Van der Peet [1996] 2 SCR 507; Delgamuukw v Attorney General of British Columbia [1997] 3 SCR 1010; and Tsilhqot'in Nation v British Columbia [2014] 2 SCR 256. In Australia and New Zealand, the courts have modernised the doctrine of tenure by holding that the Crown's radical title is subject to pre-existing property rights as defined by Indigenous law and custom: Mabo v State of Queensland (No 2) (1992) 175 CLR 1; and Attorney-General v Ngāti Apa [2003] 3 NZLR 643 (CA). 
exclusivity and absolute ownership. ${ }^{14}$ This fails to recognise that these rights may exist in relation to one another in accordance with the overarching principle of reciprocity. ${ }^{15}$

Overlapping claims are said to be "almost impossibly complicated"16 and plagued by "[a] complexity of issues and interrelationships" when the orthodox rules and procedures of the State legal system are applied. ${ }^{17}$ This approach has led to a significant lacuna in the regulation of overlapping claims which has shifted the responsibility onto Māori to reach a resolution, subject to the colonial constraints of the Treaty settlement framework. ${ }^{18}$ The problem is that a resolution according to the settlement framework is inconsistent with the understanding and regulation of these rights according to tikanga. Hence, overlapping claims will never appropriately be resolved in the way that the Crown seeks, so long as the recognition framework continues to deny the existence of protocols which govern these rights according to Māori customary law.

Māori customary law is not equivalent to tikanga, though the two are inextricably linked. ${ }^{19}$ Customary law is guided by principles (also known as "conceptual regulators") that are grounded in the practice of tikanga. Applying these conceptual regulators to overlapping claims disputes allows for the extrapolation of broader legal principles which serve to govern the relationships between groups. Edward Durie has identified the following principles that form the basis of the Māori legal order: whanaungatanga (relationships); whakapapa (genealogy); mana (spiritually sanctioned authority); utu (reciprocity); kaitiakitanga (stewardship); and tapu and noa (complimentary opposites that operate on a spiritual and natural level to restore balance) ${ }^{20}$ In overlapping claims disputes, the preservation of relationships through the maintenance of reciprocal obligations is fundamental to

14 James Tully "Aboriginal Property and Western Theory: Recovering a Middle Ground" in Ellen Frankel Paul, Fred D Miller Jr and Jeffrey Paul (eds) Property Rights (Cambridge University Press, Cambridge, 1994) 153 at $168-169$.

15 Edward Taihakurei Durie Custom Law (Treaty of Waitangi Research Unit, Research Paper, Victoria University of Wellington, 1994) at 84.

16 Ngāti Hurungaterangi v Ngāti Wahiao [2017] NZCA 429, above n 4, at [16]; and Richard Boast The Native Land Court Volume 1 1862-1887: A Historical Study, Cases and Commentary (Brookers, Wellington, 2013) at 889 .

17 Waitangi Tribunal The Port Nicholson Block Urgency Report (Wai 2235, 2012) at 3.

18 Baden Vertongen "Legal Challenges to the Treaty Settlement Process" in Nicola R Wheen and Janine Hayward (eds) Treaty of Waitangi Settlements (Bridget Williams Books, Wellington, 2012) 65 at 75.

19 Carwyn Jones "Māori Dispute Resolution: Traditional Conceptual Regulators and Contemporary Processes" in Morgan J Brigg and Roland Bleiker (eds) Mediating Across Difference: Oceanic and Asian Approaches to Conflict Resolution (University of Hawai'i Press, Honolulu, 2011) 115 at 118.

20 Jones, above n 19, at 119; Durie, above n 15, at 4-5; Jackson, above n 3, at 247; and Mikaere, above n 3, at 255. 
achieving a state of ea (equilibrium). ${ }^{21}$ These principles underpin the ways in which different groups create and maintain relationships with one another.

The fluidity of Māori social organisation has always required extensive protocols for intragroup and intergroup cooperation. These protocols are based on both the kinship obligations of those with ancestral connections to the land, and the principle of reciprocity which grants neighbouring groups rights to use the land. ${ }^{22}$ The Māori term "take" is used to define the ancestral source of a right, which may be characterised as a residual right inherent in the land based on whakapapa. In contrast, "use rights" are conditional as they derive their legitimacy from the relationship with those who possess ancestral rights. ${ }^{23}$ The mutual respectability of these rights hinges upon the principle of reciprocity. In other words, those with use rights would make a regular contribution to the hapū who possessed ancestral rights to the land. ${ }^{24}$ If the relationship to the hapu, and thereby the land, was continually maintained, then such rights were passed down to descendants. As a result, inchoate rights existed by reference to past associations and whakapapa. ${ }^{25}$ Edward Durie has conceptualised the different intensities of rights as follows: primary (by descent and residence), secondary (by descent but not residence), contingent (by descent with an intention to return) and permissive (by residence but no descent). ${ }^{26}$ These categories do not represent rankings or predominance for the purposes of absolute ownership; rather, they illustrate the broader tikanga matrix in which overlapping rights to land were acquired, lost or maintained. ${ }^{27}$

The simplification of Māori land rights in terms of idealised patterns of exclusive and absolute ownership has resulted in the law on overlapping claims becoming dysfunctional, rigid and divorced from community relationships. ${ }^{28}$ The conversion of use rights to absolute ownership or exclusivity over a defined area in the current recognition framework ignores the extent to which these rights are subject to the extensive protocols concerned with the maintenance of community relationships. ${ }^{29}$ The importance of tikanga concepts such as whakapapa, ahikāroa (fires of occupation) and mana whenua (authority in relation to land) illustrates the extent to which the granting of exclusive proprietary

21 For further commentary see Waitangi Tribunal The Hauraki Settlement Overlapping Claims Inquiry Report (Wai 2840, 2019) at 93.

22 Durie, above n 15, at 66-67.

23 At 66.

24 At 69.

25 At 70.

26 At $70-72$.

27 At $80-81$.

28 At 67.

29 At 84. 
rights, independent of community relations, is problematic. This article has noted that occupation or residence may exist in relation to both ancestral rights and use rights. ${ }^{30}$ Thus, although mana whenua may be strengthened by the maintenance of ahikāroa, the centrality of whakapapa requires that descent rights will always denote a stronger connection to the land than purely occupational rights. ${ }^{31}$ However, this centrality should not be equated with absolute and exclusive ownership. ${ }^{32}$ Mana whenua has always been exercised alongside the complimentary use of occupational rights held by other groups. ${ }^{33}$ As a result, both mana whenua and ahikāroa have a considerable degree of overlap and are intrinsically linked. The comparability of these concepts with exclusive and absolute rights to land under the State legal system continues to suppress the interdependent relations which seek to govern the exercise of those rights.

The complex layers of these rights should not be divorced from the cultural context in which they operate. Any recognition of these rights within the Treaty settlement framework must accommodate the extent to which these rights are permitted to exist in harmony. As such, the amalgamation of these rights into categories of redress premised on Western notions of property has created disputes between Māori, where such disputes did not exist under tikanga.

\section{CONTRADICTIONS IN THE STATE LEGAL SYSTEM}

\section{A The Interaction between Tikanga Mäori and Colonial Law}

What may lie behind a challenge to overlapping claims is found in the interaction between the first and second laws of Aotearoa New Zealand: tikanga Māori and colonial law. The first law, brought by Kupe's people, is a values-based system primarily built around kinship. It was a legal system for small communities in which constant reciprocity was key to community relationships. ${ }^{34}$ The second law, brought by Cook's people, defined relationships primarily by contract rather than kinship. It emphasised the autonomous individual and self-determination through freedom of choice over one's

30 See "Ahikāroa" in Richard Benton, Alex Frame and Paul Meredith (eds) Te Mātāpunenga: A Compendium of References to the Concepts and Institutions of Māori Customary Law (Victoria University Press, Wellington, 2013) at 33-37.

31 See the definition of "Mana Whenua" in Richard Benton, Alex Frame and Paul Meredith (eds) Te Mātāpunenga: A Compendium of References to the Concepts and Institutions of Māori Customary Law (Victoria University Press, Wellington, 2013) at 178-179; and Hirini Moko Mead Tikanga Māori: Living by Māori Values (Revised ed, Huia, Wellington, 2019) at 296.

32 Durie, above n 15, at 84-85; Waitangi Tribunal The Tāmaki Makaurau Settlement Process Report (Wai 1362, 2007) at 105; and The Port Nicholson Block Urgency Report, above n 17, at 25.

33 Durie, above n 15, at 85-88.

34 Joseph Williams "Lex Aotearoa: An Heroic Attempt to Map the Māori Dimension in Modern New Zealand Law" (2013) 21 Wai L Rev 1 at 5. 
self and property. ${ }^{35}$ The second law tends to make a clear separation between law and culture, whereas the first law sees the principle of reciprocity and the relationships between rights-holders as being inherent to how the law should operate. ${ }^{36}$ Thus, disputes arise from the inevitable friction between the two different cultural systems, particularly where rights grounded in tikanga are made subject to a colonial system. ${ }^{37}$

To achieve reconciliation between groups with overlapping interests, parties continue to seek direct engagement with their tikanga by the Crown. ${ }^{38}$ According to tikanga, it is not necessarily about the "sameness" of an interest, rather it is about understanding difference that best promotes the legitimacy of different rights in relation to land. ${ }^{39}$ These differences can only be recognised within a broader relational framework that promotes the continuity of whanaungatanga and manaakitanga (nurturing relationships) between groups. ${ }^{40}$ The recognition framework must therefore be capable of giving effect to the tikanga matrix in which overlapping rights and interests exist in relation, rather than in opposition, to one another.

\section{B The Crown's Duty to Avoid Creating Fresh Grievances}

The Crown's duty to avoid creating fresh grievances is central to the preservation of relationships. However, the settlement process is unable to sustain relationships among groups with overlapping rights as it fails to recognise the necessary tikanga (protocols) to ensure that these rights can be exercised harmoniously. The inability of settlement redress to provide arrangements for reciprocity continues to emphasise conflict between rights-holders, rather than cooperation. The Waitangi Tribunal has repeatedly emphasised that the Crown should not create new wrongs when settling the injustices of the past. ${ }^{41}$ Although the Crown's failure to avoid creating fresh grievances has been

35 Williams, above n 34, at 6.

36 Joseph, above n 3, at 82.

37 Moana Jackson The Māori and the Criminal Justice System: A New Perspective - He Whaipaanga Hou (Part 2) (Department of Justice, Study Series 18, November 1988) at 45.

38 Colin McKenzie and Amster Reedy "A Treaty of Waitangi, Overlapping Claim Mediation: 'A Prospective Hindsight"" (2001) 9 Resource Management Journal 1 at 2.

39 Moana Jackson, Wayne Ngata and Tahu Potiki The Findings of the Adjudication Panel in the Mana Whenua Process: Convened by the Central North Island Iwi for Te Kaingaroa a Haungaroa Crown Forest Licenses (26 June 2014) at 11-12.

40 At 9 .

41 See for example Hauraki Report Settlement Overlapping Claims Inquiry Report, above n 21, at 93:

The Crown has a duty to protect all parties, whether settled or not, and to promote and maintain relationships with all tangata whenua groups [...] The Tribunal found in The Tämaki Makaurau Settlement Process Report that the Crown... must proactively seek to avoid damaging relationships between iwi. 
recognised by the Tribunal, ${ }^{42}$ I would go further to suggest that the Crown's deliberate inaction has played an active role in creating disputes. An example of this is the mediation of overlapping rights between Ngāti Tama and Ngāti Maniapoto. Ngāti Maniapoto approached the mediation as a Māori dispute resolution process, concentrating on their rights as derived from tikanga. In contrast, Ngāti Tama based their rights on the negotiated terms of the settlement redress and were focused on concluding their settlement. ${ }^{43}$ Ngāti Tama was therefore able to reconceptualise their rights in accordance with the type of redress to which the settlement process itself prioritises. ${ }^{44}$

The principle of partnership places a duty on the Crown to consult with groups that have overlapping interests. In particular, the duty to avoid creating fresh grievances requires that the Crown "fully understand all parties' overlapping interests". ${ }^{45}$ While this may result in new issues and potentially new forms of redress, it is part of the Crown's duty to engage meaningfully with groups who have overlapping interests. More significantly, it must "test out" its understanding of those interests with groups when developing redress proposals. ${ }^{46}$ This is a clear signal that any redress must therefore be informed by the substance of those rights as determined by tikanga. Although the Crown says that settlement redress is not intended as a "reflection of mana whenua", it is often perceived by those groups as an "expression of ... mana whenua status within the rohe [defined area/territory] in which the redress lies". ${ }^{47}$ As a result, the Crown cannot distance itself from the practical consequences of offering redress to groups in certain areas where strong interests are held by others. Settlements should not be at "all costs" and damage to tribal relations should be kept to the absolute minimum. ${ }^{48}$

See also The Port Nicholson Block Urgency Report, above n 17, at 59 where the Tribunal remarked that: "The Tribunal has [previously] emphasised that the Crown should not create new wrongs when settling the injustices of the past". Finally, in The Tämaki Makaurau Settlement Process Report, above n 32, at 101 the Tribunal observed that:

The importance of whanaungatanga relates to the guarantee of tino rangatiratanga in Article II. It emphasises the need for the Crown to: understand the relationships ... between all groups; act wherever possible to preserve amicable tribal relations; and act fairly and impartially towards all iwi, not giving unfair advantage to one, especially in situations where inter-group rivalry is present ...

42 Waitangi Tribunal The Hauraki Settlement Overlapping Claims Inquiry Report, above n 21, at 86-92.

43 Mereana Hond "Resort to Mediation in Māori-to-Māori Dispute Resolution: Is it the Elixir to Cure All Ills?" (2002) 33 VUWLR 155 at 162.

44 For further commentary see Jones, above n 6, at 128.

45 Waitangi Tribunal The Hauraki Settlement Overlapping Claims Inquiry Report, above n 21, at 75.

46 At 82

47 At $84-85$.

48 Waitangi Tribunal The Port Nicholson Block Urgency Report, above n 17, at 59. 
Therefore, the provision of exclusive redress to one group over another is contrary to "the long term reconciliation of Crown and Māori that the settlements seek to achieve."49

The understanding of overlapping rights is fundamental to the Crown's duty to avoid creating fresh grievances. The problem is that redress is conceptualised by a colonial recognition framework. Thus, overlapping rights are only understood to the extent that they conform to the recognition framework, which usually requires that some groups are afforded absolute proprietary rights at the expense of any reciprocal arrangements that would otherwise exist between different rights-holders under tikanga. As a result, the Crown will continue to actively create disputes between Māori unless redress becomes capable of recognising the extent to which rights depend upon reciprocal mechanisms to preserve indigenous relationality.

\section{THE SUPREMACY OF THE COLONIAL RECOGNITION FRAMEWORK}

The Crown's policy guidance on how to resolve overlapping claims within the Treaty settlement context, Ka tika à muri, ka tika à mua - Healing the Past, Building a Future (The Red Book), empowers Māori to resolve these disputes only in so far as they suppress their own tikanga to fit within the colonial recognition framework. This way, the Crown purports to absolve itself of any responsibility, while tightly controlling the extent to which overlapping claims must be resolved. I argue that both exclusive and non-exclusive redress fail to recognise overlapping rights as tikanga rights. Non-exclusive redress fails due to its reliance on creating statutory instruments which are only concerned with vesting ownership in fee simple, providing beneficial entitlements or acknowledgements of association with reserve land. These types of redress only go as far as providing Māori with limited consultation rights, delegitimising the substance of those rights as sourced in Māori law. The problem is that tikanga does not provide the legal framework for determining when alternative forms of redress should be employed, what that redress should look like from a tikanga lens, and how it might ensure the preservation of relationships.

\section{A The Overlapping Claims Process and the Suppression of Tikanga Māori}

There is a significant lacuna in the law relating to how the customary rights and interests of claimants who are not engaged in negotiations with the Crown should be addressed; particularly when their neighbours proceed to settlement. The Red Book notes that the Crown's preference is for parties

49 Waitangi Tribunal The Ngāti Awa Settlement Cross-Claims Report (Wai 958, 2002) at 88, as cited in Waitangi Tribunal The Port Nicholson Block Urgency Report, above n 17, at 59. 
themselves to resolve overlapping claims disputes and that where this proves unsuccessful, the Crown will engage in a balancing exercise subject to the following objectives: ${ }^{50}$

1. ... to reach a fair and appropriate settlement with the claimant group in negotiations, and

2. ... to maintain, as far as possible, its capability to provide appropriate redress to other claimant groups and achieve a fair settlement of their historical claims.

Theoretically, this empowers Māori to resolve overlapping claims in accordance with tikanga, seemingly going beyond the colonial framework. However, this is undermined by the Crown's power to intervene when no 'acceptable' resolution has been achieved by the parties themselves. Thus, the opportunity to engage tikanga on the matter is subsumed by the colonial framework. The balancing of interests would then take place against the Crown's principal objectives, displacing the principle of reciprocity and the centrality of relationships that would otherwise be required under tikanga. These concepts of justice should ultimately inform the reasoning for what is considered a fair and appropriate settlement. Iwi and hapū are therefore deprived of a forum in which they can seek authoritative determinations of customary rights and interests in accordance with tikanga. Many disputes remain unresolved and proceed to litigation as a result.

\section{B The Recolonisation of Rights for Redress}

The ultimate measure of a "fair and appropriate" settlement should be the extent to which the redress is capable of accommodating the different customary rights and interests in relation to land. The Red Book refers to the Ngāti Awa Raupatu Report which provides that: ${ }^{51}$

[T] he essence of Māori existence was founded not upon political boundaries, which serve to divide, but upon whakapapa or genealogical ties, which served to unite or bind. The principle was not that of exclusivity but that of associations.

The Crown says its approach is consistent with these findings by virtue of its preference to offer non-exclusive redress where overlapping claims exist. ${ }^{52}$ However, The Red Book suggests that exclusive redress may be considered where a claimant group has a "strong enough association with a site to justify this approach (taking into account any information or submissions about the association of overlapping claimants with that site)" ${ }^{53}$ I argue that Māori are more likely to reconceptualise their

50 Te Arawhiti: Office for Māori-Crown Relations Ka tika ā muri, ka tika ā mua: Healing the past, building a future - A Guide to Treaty of Waitangi Claims and Negotiations with the Crown (2018) [The Red Book] at 54.

51 At 53

52 At 54

53 At 55 . 
rights in accordance with the type of redress prioritised by the settlement process to avoid lesser forms of recognition, such as associational rights.

Although these other types of redress are "non-exclusive" in a strict sense, the statutory instruments providing legal recognition of rights are premised on Western concepts of vesting ownership in fee simple estate and deriving a particular beneficial entitlement. ${ }^{54}$ Paradoxically, this is precisely the type of redress in which tikanga does not really speak. Other mechanisms include the provision of overlay classifications, which impose consultation obligations on the Department of Conservation to engage with the parties on matters of significance. ${ }^{55}$ Whether something is a matter of significance depends upon the authority's interpretation of what necessitates consultation, therefore depriving iwi and hapū of any real decision-making powers. The Crown may also decide to vest reserves subject to the Reserves Act 1977, in which the claimant group becomes the administering body of the reserve. This provides for a limited form of autonomy, subject to the legislative provisions. ${ }^{56}$ Furthermore, the Crown may include a statutory acknowledgement of any cultural, historical, spiritual and/or traditional associations with an area. These acknowledgements confer limited forms of legal obligations on the parties, including notification of resource consents and a requirement that the authority must "have regard to" any associations when deciding whether Māori have a right to be heard at proceedings affecting those sites. ${ }^{57}$

Ultimately, these forms of redress provide, at best, a consultation entitlement or some type of administrative authority subject to legislative parameters. Non-exclusive redress does not go much further than exclusive redress in the sense that both mechanisms fail to account for how overlapping rights may be recognised within the cultural context from which they derive. The majority of instruments available for non-exclusive redress focus on historical associations with land, without providing any real means for the contemporary exercise of those rights or managing those rights subject to the principle of reciprocity so as to protect indigenous relationality.

\section{Indigenous Relationality through the Restoration of Mana}

The interventionist approach to resolving overlapping claims has shifted the focus away from preserving the relationship between parties towards ensuring tikanga rights are only legitimised by satisfying the objectives of the Crown. It is important that the satisfaction of the Crown and the duty to preserve relationships are not conflated. The Crown's principal objectives may, at times, be inconsistent with the means necessary to recognise the mana of both groups in a way that maintains amicable relations.

54 At 116-119.

55 At 121 .

56 At 120 .

57 At 122 . 
The Crown must exercise its role as an "honest broker" to effect reconciliation. ${ }^{58}$ Even if the parties themselves are motivated to strike a deal at a cost to their relationship, the Crown's focus must be broader, for those parties are only in that position because of breaches by the Crown. ${ }^{59}$ It is not enough for the Crown to act in good faith only in so far as customary interests are legitimised against the objectives of the settlement process that are defined and determined solely by the Crown. The Crown must take an expansive approach and gain a sophisticated understanding of modern-day tribal relations. ${ }^{60}$ This speaks to the acknowledgement of mana as an essential component for positive relationships going forward, thus ensuring the durability of settlements. ${ }^{61}$ Although this acknowledgement may seem relatively insignificant to the Crown, the failure to understand relationships may result in an increased appearance of mana in one group, therefore, diminishing another group's mana. ${ }^{62}$

Despite the limitations of the Treaty settlement framework, overlapping claims disputes are situations in which tikanga must speak. The existence of any reciprocal arrangements between groups, in order to maintain relationships, rests upon a mutual respectability of mana.

\section{IMPLEMENTING TIKANGA AS THE JURISDICTIONAL FRAMEWORK}

Implementing tikanga as the jurisdictional framework for resolving overlapping claims would, in my view, demonstrate a shift towards the promotion of whanaungatanga and manaakitanga between parties. Below, I elaborate on why tikanga ought to be adopted as the jurisdictional framework going forward.

\section{A Ka Tika a Muri, Ka Tika ä Mua?}

The Tämaki Makaurau Settlement Process Report is the cornerstone report condemning the Crown's approach to overlapping claims. In this report, the Waitangi Tribunal found the Crown had relied too heavily on its relationship with Ngāti Whātua o Ōrākei (Ngāti Whātua), given that its relationship with other tangata whenua groups was "no more and no less" the same in Treaty terms. ${ }^{63}$ Furthermore, the Crown was found to be "denying reality" by providing exclusive redress to Ngāti

58 Waitangi Tribunal The Ngāti Awa Settlement Cross-Claims Report (Wai 958, 2002) at 88.

59 Waitangi Tribunal The Ngāti Tüwharetoa ki Kawerau Settlement Cross-Claim Report (Wai 996, 2003 ) at 53.

60 At 61 .

61 Waitangi Tribunal The Ngāti Maniapoto/Ngāti Tama Settlement Cross-Claims Report (Wai 788, Wai 800, 2001) at 15 and 21.

62 Waitangi Tribunal The Ngāti Tūwharetoa ki Kawerau Settlement Cross-Claims Report, above n 59, at 60.

63 Waitangi Tribunal The Tāmaki Makaurau Settlement Process Report, above n 32, at 18. 
Whātua when it had failed to weigh the "dense layers of interest" of all tangata whenua groups. ${ }^{64}$ As a result, it concluded that the finding of "predominant" interests was the wrong approach to adopt where there are multiple interests at play. ${ }^{65}$ Despite the fact that Ngāti Whātua had failed to engage with other groups concerning their overlapping interests, the Tribunal found that it was wrong for the Crown to absolve itself of its overriding duty to preserve relationships in exchange for expediency. ${ }^{66}$

Subsequently, the Port Nicholson Block Urgency Report reaffirmed this approach, emphasising the Crown's duty to avoid creating fresh grievances. ${ }^{67}$ The report coined the term "the silo approach" in referring to a situation where negotiations involving overlapping interests are conducted in relative isolation, without any clear overview of how those interests intersect and how the redress offered might affect those interests. ${ }^{68}$ The Tribunal concluded that "[t]he burden on both Māori and Pākehā of the great wrongs that were done in the past will not be lifted if the process of settling creates new wrongs." 69

Nevertheless, the Crown's approach to overlapping claims remains unchanged. In light of this, the Hauraki Settlement Overlapping Claims Inquiry Report emphasises how tikanga may be used to assist the Crown in upholding its duty to avoid creating fresh grievances. This report noted for the first time that a values-based approach to overlapping claims was encompassed by The Red Book's title: Ka tika $\bar{a}$ muri, ka tika a mиa (if the support given from the back is consistent with tikanga, then the work of those at the front will be successful). ${ }^{70}$ Despite this, The Red Book was found to be "essentially silent on the subject". ${ }^{71}$ Although the policy aims to empower Māori to implement their own processes for resolving disputes, it does not require those interests or redress to be informed by tikanga. Nor does it "require the Crown to actively support or monitor tikanga-based processes". ${ }^{72}$ The report encourages the use of tikanga as the jurisdictional framework on the basis that adopting a valuesbased approach is likely to improve the substance of the decision, in that "a satisfactory outcome for all groups is even more likely". ${ }^{73}$ This requires the Crown to move away from a one-size-fits-all

64 At $47-48$.

65 At 105 .

66 At $50-53$.

67 Waitangi Tribunal The Port Nicholson Block Urgency Report, above n 17, at 59.

68 At 60.

69 At 64 citing Waitangi Tribunal The Tāmaki Makaurau Settlement Process report, above n 32, at 2.

70 In other words, "healing the past, building a future" as adapted by the Office for Māori-Crown Relations, above $\mathrm{n} 49$.

71 Waitangi Tribunal Hauraki Settlement Overlapping Claims Inquiry Report, above n 21, at 86.

72 At $86-87$.

73 At 89 . 
model, by empowering processes that are designed and implemented in terms of the parties' own values, relationships and circumstances. To that end, the report provides a list of principles and practices which serve to guide tikanga-based processes with the aim of developing, regulating and maintaining relationships. ${ }^{74}$ In summarising its approach, the Tribunal suggests that implementing tikanga as the legal framework for resolving overlapping claims provides an opportunity for the Crown to empower parties to transform their relationships "using traditional practices, customs, and values to resolve issues of tribal significance." 75 This process seeks to empower the exercise of rangatiratanga beyond the confines of the colonial recognition framework.

The use of tikanga-based processes for resolving overlapping claims is an essential part of the Crown's duty to avoid creating fresh grievances. Although there is a lack of distinct policy on whether tikanga is the appropriate starting point, it is nevertheless inherent in the spirit and intent of The Red Book. Over the last decade, the Waitangi Tribunal has consistently endorsed the view that such processes are necessary in order for the Crown to discharge its obligations under the Treaty of Waitangi. In giving effect to tikanga, the Crown must ensure that such processes are determined by the parties themselves, and that the balancing of interests remains subject to the preservation of relationships. What is clear is that customary rights exist to be governed by tikanga and thus, any legal recognition or reconciliation of those rights must be guided by a jurisdictional framework grounded in those practices, principles and values.

\section{B The Opportunity in Alternative Dispute Resolution}

The failure to recognise tikanga as an equal system of law continues to leave parties without a sense of justice. As a result, Māori are increasingly bringing their disputes into the courts, along with their tikanga. Although tikanga has been recognised as being part of the values of the common law, it is interpreted only in so far as it conforms to the underlying values of Western law. ${ }^{76}$ The corollary is that tikanga is often balanced out against other legal principles, or fashioned into a narrowly defined set of proprietary rights constrained by the colonial recognition framework. ${ }^{77}$ I argue that there is an opportunity in alternative dispute resolution processes, such as arbitration and mediation, to reconceptualise rights in accordance with tikanga.

Alternative dispute resolution processes may allow parties to implement tikanga as the applicable law for resolving disputes, therefore providing for a limited form of jurisdictional autonomy. This

74 At 90 .

75 At 91 .

76 Jacinta Ruru "The failing modern jurisprudence of the Treaty of Waitangi" in Carwyn Jones and Mark Hickford (eds) Indigenous Peoples and the State: International perspectives on the Treaty of Waitangi (Routledge, New York, 2019) 111 at 118-122; Joseph, above n 3, at 91-92; and Williams, above n 34, at 1722.

77 Hond, above n 43, at 583 . 
supports the proposition that Māori customary rights exist to be governed by tikanga and that the legal recognition framework must adapt to realise this. ${ }^{78}$ This provides a basis for which Māori legal traditions and the State legal system interact with each other by recognising tikanga as an equal system of law.

Amokura Kawharu has argued that alternative dispute resolution processes allow tikanga to apply in a way that is not likely to happen in the courts. ${ }^{79}$ By recognising tikanga as a jurisdictional framework, decision-makers are provided with the necessary means to reconceptualise the ways in which the adversarial court system understands the breakdown of relationships and how those should be restored within the appropriate cultural context. ${ }^{80}$ To achieve a state of ea, the dispute must be viewed as a relational event. 81

Overlapping rights represent the relationships that exist between different groups and the land. Thus, a relational approach to justice is required so that redress is properly informed by the substance of the right. ${ }^{82}$ Relational approaches are emphasised in settlement deeds and terms of reference in relation to the determination of mana whenua. Oral histories (including whakapapa, waiata and tribal history) and written sources (including Native Land Court and Waitangi Tribunal evidence and decisions) are used in a way that promotes "whanaungatanga, manaakitanga and kotahitanga" among the respective iwi. ${ }^{83}$ A relational approach uses history to inform how those rights should be exercised in the present. History tells us that these rights exist to be governed by relational protocols and that the present recognition framework must be capable of providing such protocols. In support of this, the Adjudication Panel in the Central North Island (CNI) Iwi Mana Whenua Process noted that while there had been disputes in meaning, there was an acceptance of the right of each iwi to tell their stories "for themselves, on their own terms, answerable to one another" ${ }^{84}$

This raises more questions as to whether the application of tikanga in this context has been successful in reaching a resolution that is not only accepted by each party individually, but also provides for the relationship to be maintained. There are many external factors that will influence a party's acceptance of an outcome. The appeal of an award does not mean that tikanga, as a legal

78 Kawharu, above n 1, at 301-302.

79 At $308-309$.

80 Jackson, above n 37 , at 40-45.

81 Stephanie Vieille "Māori Customary Law: A Relational Approach to Justice" (2012) 3(1) IIPJ 1 at 5-6.

82 Robert Joseph "Unsettling Treaty Settlements: Contemporary Māori Identity and Representation Challenges" in Nicola R Wheen and Janine Hayward (eds) Treaty of Waitangi Settlements (Bridget Williams Books, Wellington, 2012) 151 at 152-156.

83 Ngāti Hurungaterangi v Ngāti Wahiao [2017] NZCA 429, above n 4, at [33]-[36]; and Jackson, Ngata and Potiki, above n 39, at 16 .

84 Jackson, Ngata and Potiki, above n 39, at 19 (emphasis added). 
framework, is ineffective. One factor which must be considered is the availability of settlement redress. ${ }^{85}$ The problem is that the current recognition framework does not provide redress which is capable of giving effect to overlapping rights, as it denies the opportunity for these rights to co-exist. It, therefore, becomes an impossible task for tikanga to achieve a state of ea between parties where redress only recognises those rights to the extent that they fit within the colonial parameters of the Treaty settlement framework. ${ }^{86}$

\section{Incorporating Tikanga Principles into Mainstream Dispute Resolution}

The implementation of tikanga principles within a mainstream dispute resolution process is often an under-recognised step in ensuring that processes are acceptable to parties and maximise the durability of resolutions. ${ }^{87} \mathrm{~A}$ values-based inquiry moves away from solutions based on competing notions of exclusivity towards a focus on the protocols for reciprocity between parties.

For example, the mediators involved in the Ngāti Tama and Ngāti Maniapoto settlement have questioned whether the mediation process itself was limited by not giving sufficient recognition to the underlying tikanga values that drive Māori dispute resolution processes. ${ }^{88}$ The provision of a tikanga-based framework would have allowed parties to gain a better understanding of tikanga concepts in a way that emphasised "who" the parties were in relation to each other, rather than "what" the parties wanted in a final protection mechanism. ${ }^{89}$ From this perspective, the resolution process is focused on mediating across differences in order to maintain relationships, as opposed to leveraging those differences to achieve a particular outcome. The mediators argue that values-based disputes should not be re-framed as some sort of interest-based dispute, as this too quickly channels such issues into court which leads to the frustration of those relationships. ${ }^{90}$

One example where tikanga has flourished as a jurisdictional framework within a mainstream dispute resolution process is the CNI Iwi Mana Whenua Process. In this process, once mana whenua had been established, these rights were subject to "the need to respect and indeed manaaki the interests and rights of others." 91 Although the adjudication panel (the Panel) recognised the need for balancing different interests, those differences had to be balanced "in order to promote 'whanaungatanga,

85 Vertongen, above n 18, at 67; and Hond, above n 43, at 163-165.

86 Maria Bargh "The Post-Settlement World (So Far): Impacts for Māori" in Nicola R Wheen and Janine Hayward (eds) Treaty of Waitangi Settlements (Bridget Williams Books, Wellington, 2012) 166 at 173-174.

87 Jones, above n 19, at 136.

88 McKenzie and Reedy, above n 38, at 3 and 6.

89 At 4.

90 At 5 .

91 Jackson, Ngata and Potiki, above n 39, at 8. 
manaakitanga, and kotahitanga amongst the iwi."'92 This shows that where tikanga is the jurisdictional framework for such disputes, the balancing of differences remains subject to the preservation of relationships. The difference is that indigenous relationality becomes the paramount consideration. More importantly, just because tikanga aims to preserve relationships does not mean that is incapable of balancing out differences in order to reach a resolution. Instead, such balancing is permitted in so far as it promotes whanaungatanga and manaakitanga.

In giving effect to tikanga, the Panel found that the single title model was not always adequate for recognising the relationship between the parties who hold mana whenua. In some instances, alternative mechanisms may be required to ensure "respectful and ongoing cooperation based on whakapapa relationships". The Panel went further to say "there are quite distinct and varying interests and applications of mana whenua that represent equally distinct histories and traditions. Each is valid and each is worthy of respect."93

This shows that where tikanga provides the jurisdictional framework, there is scope to move beyond recognition that is based on absolute and exclusive ownership. There are existing legal mechanisms which can play a formal role in preserving the integrity of overlapping customary rights and interests. Furthermore, there is a balancing exercise unique to a values-based framework grounded in tikanga. Such an approach provides for the mediation of differences in a way that promotes indigenous relationality and mechanisms for reciprocity.

\section{LIMITATIONS OF THE COURTS: SUBJUGATING TIKANGA MÄORI TO WESTERN LAW}

\section{A The Deprivation of Māori Jurisdictional Autonomy by the Courts}

The increasing litigation over awards arising out of alternative dispute resolution processes suggests that it is up to the courts to ensure that tikanga has been appropriately applied to overlapping claims. However, this article acknowledges that the courts are not the best forum for doing so. This position is best illustrated by the Ngāti Hurungaterangi $v$ Ngāti Wahaio litigation concerning the appeal of an arbitration award which decided lands would be jointly and equally held between Ngāti Whakaue and Ngāti Wahaio. ${ }^{94}$ The Trust Deed provided that arbitration was to be the primary mechanism for resolving overlapping claims disputes and that land would be held on trust until ownership issues were resolved. ${ }^{95}$ The parties appealed the decision on the basis that the arbitral tribunal had failed to have regard to mana whenua as "the mana that Iwi/hapū/individuals traditionally

92 At 8 .

93 At $11-12$.

94 Ngāti Hurungaterangi v Ngāti Wahiao [2016] NZHC 1486, above n 7, at [54].

95 At [27]-[32]. 
held and exercised over the land, determined according to tikanga" pursuant to clause 15.4 of the Trust Deed. ${ }^{96}$

The underlying approach of both the High Court and the Court of Appeal was that overlapping claims disputes are simply incapable of judicial resolution. I argue that such a view is underpinned by the misconception that judicial standards should only be construed in accordance with Western sources of law. However, if tikanga is part of New Zealand law, it is erroneous to say that such disputes are irreconcilable. Tikanga, as a system of law, provides a values-based framework capable of mediating these differences, with the aim of preserving the relationship between the parties.

The High Court described the different historical accounts given by each party as "contradictory and simply incapable of resolution adopting convention[al] judicial methods." 97 This depended upon the Court's interpretation that "the applicable principles of tikanga themselves were hotly contested". ${ }^{98}$ Although the Court of Appeal did not directly address this issue, it framed the dispute as one which was "'almost impossibly complicated, characterised by large numbers of overlapping claims and claimant groups."'99 Such an approach is misconceived because, despite the variegating practices of tikanga, the principled framework in which those practices operate remains largely uncontested. ${ }^{100}$ Although there may be multiple interests in land which are unable to co-exist in accordance with Western sources of law, this does not mean that the tikanga principles themselves are contested or that tikanga should not be regarded as law. Rather, this illustrates that where Western judicial methods are incapable of resolving disputes, tikanga must be employed as the proper legal framework under which disputes can be resolved. However, the High Court instead adopted a "holistic" approach to identify "where the balance of beneficial ownership interests lie in accordance with the imprecise and changeable aspects of tikanga." 101 This shows that even where the substance of those rights are sourced in a Māori legal system, the courts will use the diversity in tikanga to justify applying a standard that is "holistic" only in accordance with Western sources of law.

This approach was compounded by the fact that the arbitration process had engaged with only Western sources of law, despite the Panel being required to decide mana whenua in accordance with tikanga. ${ }^{102}$ Although the High Court upheld the Panel's reasoning, it had described its lack of

96 At [34] (emphasis added).

97 At [121].

98 At [129].

99 Ngāti Hurungaterangi v Ngāti Wahiao [2017] 3 NZCA 429, above n 4, at [16].

100 See Part III in this article on "Overlapping Rights through the Lens of Indigenous Relationality".

101 Ngāti Hurungaterangi v Ngāti Wahiao [2016] NZHC 1486, above n 7, at [130] (emphasis added).

102 At [34]. 
engagement as "regrettable"103 and "limited". 104 The Court of Appeal overturned the High Court's decision on the basis that the complexity of the interests did not absolve the Panel from "its fundamental duty to determine ownership by reference to mana whenua". ${ }^{105}$ The significance of this approach is that the Court of Appeal rejects the notion that the complexity of overlapping claims will justify a lack of engagement with tikanga on the matter. The problem, however, is that the Panel is required to determine what customary rights exist according to tikanga, while simultaneously positioning those rights within a colonial recognition framework in deciding who should be entitled to redress. The paradox is that the Court recognises that these rights exist to be governed by tikanga, but only to the extent they are fitted into redress premised upon Western notions of exclusivity, thus failing to provide for indigenous relationality. If tikanga can only exist in this way, this undermines any opportunity for disputes to be resolved to the satisfaction of both parties. As a result, parties are incentivised to make arguments that reconceptualise their substantive rights to be preferred by the colonial recognition framework. I argue that the legal recognition of rights must be informed by their substance to uphold indigenous relationality under tikanga.

The inability for differing applications of tikanga to be appealed is problematic. It is regrettable that the Court of Appeal did not address the High Court's treatment of whether divergent practices of tikanga could amount to an error of law. This article suggests the High Court was mistaken in using the variation of tikanga to justify why its application could not amount to an error of law. ${ }^{106}$ The relevant tikanga principles were referred to and explained in the Trust Deed underpinning the arbitral process and were known and accepted by the parties in advance. ${ }^{107} \mathrm{I}$ have argued that the principled framework for which these substantive rights are determined is commonly accepted among Māori. Therefore, the "applicable law" in this context, according to the High Court's interpretation, is understood to mean Western law, as opposed to the law chosen by parties. ${ }^{108}$ A more favourable approach would be to recognise that the parties' decision to implement Māori law must continue with any appeal to the courts. Although the court process is adversarial by nature, accepting tikanga as the appropriate jurisdiction for deciding the dispute would reconceptualise the harm as the breakdown of relationships in a way that aims to promote indigenous relationality.

103 At [120].

104 At [130].

105 Ngāti Hurungaterangi v Ngāti Wahiao [2017] NZCA 429, above n 4, at [101].

106 The High Court decision refers to Edward Durie's evidence explaining the variegating practices of tikanga at [165]-[167]; the balancing exercise in Takamore v Clarke [2012] NZSC 116 at [169]; and the evidence and proof requirements as explained by Richard Boast, above n 16, at [170]-[172].

107 Kawharu, above n 1, at 304.

108 At 306. 
The challenge is that even a proper evaluation of customary law using a principled approach grounded in tikanga continues to be measured against the colonial recognition framework. Hence, these substantive rights will continue to be negotiated to the extent that they conform to the redress offered.

\section{B Continuing the Assimilation of the Native Land Court}

The suppression of tikanga through the colonial recognition framework illustrates that the State legal system continues to perpetuate the assimilation practices of the Native Land Court. The commonality is that both the current recognition framework and the former jurisdiction of the Native Land Court fail to recognise the legitimacy of Māori law. This failure has continued to incentivise parties to reformulate their rights in colonial terms. ${ }^{109}$ This article demonstrates that there is a marked difference between rights grounded in tikanga and rights reconceptualised for the Crown. The prevalence of legal recognition frameworks grounded in Western sources of law only serves to distort the substance of a right that would otherwise be given proper recognition under tikanga.

The jurisdiction of the Native Land Court is well traversed and I do not wish to cover the same ground. ${ }^{110}$ Nevertheless, the problem with the Native Land Court was that Māori customary rights were forced into categories of ownership and exclusivity. ${ }^{111}$ This led to the legal fracturing of Māori social organisation through the divisive nature of allocating proprietary rights to one group, or persons, over others who had equal standing under Māori customary law. ${ }^{112}$ Richard Boast has emphasised that "land rights were intricate, overlapping and multi-layered" and that "[i]t is not enough to [say] that Māori land tenure was complicated; the complications have to be understood". ${ }^{113}$ Yet, similar criticisms are made in this article about the judicial assumption that overlapping claims are incapable of reconciliation.

This position is supported by the fact that redress will only go as far as granting limited forms of consultation rights to multiple parties or recognising only one party's predominant and exclusive interests in the land. There is an opportunity, however, to implement tikanga as the applicable law by

109 Te Aka Matua o te Ture/ Law Commission Māori Custom and Values in New Zealand Law (NZLC SP9, 2001) at 65.

110 See Richard Boast's multi-volume commentary: Boast, above n 16; Richard Boast The Native Land Court Volume 2 1888-1909: A Historical Study, Cases, and Commentary (Thomson Reuters, Wellington, 2015); and Richard Boast The Native/Māori Land Court Volume 3 1910-1953: Collectivism, Land Development and the Law (Thomson Reuters, Wellington, 2019).

111 Joseph Williams The Mãori Land Court: A Separate Legal System? (New Zealand Centre for Public Law, Occasional Paper 4, July 2001) at 2-4.

112 Richard Boast Buying the Land, Selling the Land: Governments and Māori Land in the North Island 18651921 (Victoria University Press, Wellington, 2008) at 107-109; and see also Williams, above n 111, at 3-4.

113 Boast, above n 110, at 108 . 
using alternative dispute resolution processes. Nevertheless, the arbitration award that was appealed in Ngāti Hurungaterangi $v$ Ngāti Wahaio suggests that these processes may sometimes fail to engage authentically with tikanga. As a result, parties are incentivised to bring their tikanga into the courts in an attempt to avoid the dilution of their rights where redress fails to preserve indigenous relationality. The courts have taken the view that overlapping claims are incapable of conventional judicial resolution and that tikanga principles are not questions of law. The corollary is that the success of tikanga as a jurisdictional framework continues to be burdened by the existence of colonial recognition frameworks which cannot appropriately account for the full nature and extent of customary rights as they exist under tikanga.

\section{CONCLUSION}

The current recognition of overlapping rights in land perpetuates the notion that tikanga rights should be assimilated into a colonial legal order. I have argued that it is problematic to assume that overlapping claims are so complex that tikanga should not be regarded as a question of law.

The Red Book fails to consider mechanisms that provide for indigenous relationality. However, the spirit and intent of The Red Book suggests that tikanga-based processes should be an essential part of fulfilling the Crown's duty to avoid creating fresh grievances. To fill this lacuna, parties continue to seek justice through alternative dispute resolution processes. These processes provide a significant opportunity to implement tikanga as the applicable law. The recognition of tikanga as the applicable law provides the framework for addressing and understanding these disputes as the breakdown of relationships. In light of this, the aim of the law should be to mediate across differences in a way that preserves the relationships between parties and to provide redress mechanisms for continuing reciprocity. In contrast, the colonial recognition framework continues to position overlapping rights against each other by either diluting parties' rights to mere consultation entitlements or by constructing a hierarchy in which only one party has predominant interests in land. Although parties continue to appeal these decisions, the courts operate on the assumption that overlapping claims are too complex for conventional judicial resolution. However, what is necessary is for these complications to be understood. I have argued that the courts must employ tikanga as the jurisdictional framework in order to understand the complex web of relationships.

Ultimately, the State legal system continues to delegitimise indigenous relationality in ways that amalgamate rights into a colonial recognition framework, which fails to recognise tikanga Māori as an equal system of law in Aotearoa New Zealand. 
APPENDIX 1: GLOSSARY OF MĀORI TERMS

\begin{tabular}{|c|c|}
\hline Ahikāroa & fires of occupation \\
\hline $\mathrm{Ea}$ & state of equilibrium \\
\hline Hapū & section of extended kin group \\
\hline Iwi & extended Māori kin group \\
\hline Kaitiakitanga & guardianship/ stewardship \\
\hline Kāwanatanga & government \\
\hline Kotahitanga & unity \\
\hline Mana & spiritually sanctioned authority \\
\hline Manaakitanga & nurturing relationships \\
\hline Mana whenua & authority in relation to land \\
\hline Noa & profane/ ordinary/ complimentary opposite of tapu \\
\hline Pākehā & New Zealanders of European descent \\
\hline Rangatiratanga & Māori self-determination/ chiefly authority \\
\hline Rohe & defined area/ territory \\
\hline Take & ancestral right \\
\hline Tangata whenua & Indigenous/ 'people of the land' \\
\hline Tapu & spiritual character of all things \\
\hline Te Ao Māori & Māori world/ worldview \\
\hline Tikanga Māori & system that encompasses Māori law \\
\hline Utu & reciprocity \\
\hline Waiata & song \\
\hline Whakapapa & genealogy \\
\hline Whanaungatanga & relationships \\
\hline
\end{tabular}


(2021) 52 VUWLR 